\title{
An Analysis of Investor's Risk Perception towards Mutual Funds Services
}

\author{
Nidhi Walia (Corresponding author) \\ Lecturer, School of Management \& Social Sciences, Thapar University \\ Patiala, India \\ E-mail: nwalia@thapar.edu \\ Dr. Mrs. Ravi Kiran \\ School of Management \& Social Sciences, Thapar University \\ Patiala, India \\ E-mail: rkiran@thapar.edu
}

\begin{abstract}
Financial markets are constantly becoming more efficient by providing more promising solutions to the investors. Being a part of financial markets although mutual funds industry is responding very fast by understanding the dynamics of investor's perception towards rewards, still they are continuously following this race in their endeavor to differentiate their products responding to sudden changes in the economy. Thus, it is high time to understand and analyze investor's perception and expectations, and unveil some extremely valuable information to support financial decision making of mutual funds. Financial markets are becoming more exhaustive with financial products seeking new innovations and to some extent innovations are also visible in designing mutual funds portfolio but these changes need alignment in accordance with investor's expectations. Thus, it has become imperative to study mutual funds from a different angle, i.e, to focus on investor's expectations and uncover the unidentified parameters that account for their dissatisfaction. Present research proposes to identify critical gaps in the existing framework for mutual funds and further extend it to understand realizing the need of redesigning existing mutual fund services by acknowledging Investor Oriented Service Quality Arrangements (IOSQA) in order to comprehend investor's behavior while introducing any financial innovations.
\end{abstract}

Keywords: Mutual Funds (MFs), Investor's expectations, Asset Management Companies (AMCs), Portfolio risk, Return on Investment (ROI), Diversification, Financial innovation, Continuous Improvement (CI)

\section{Introduction}

Mutual funds are recognized as a mechanism of pooling together the investment of unsophisticated investors and turn in the hands of professionally managed fund managers for consistent return along-with capital appreciation. Money collected in this process is then invested in capital market instrument such as shares, debentures and other securities. Finally, unit holders in proportion of units owned by them share the income earned through these investments and capital appreciation. Mutual funds put forward a way out to investors to approach most schemes and get well-diversified portfolio because investors with small savings neither have sufficient expertise nor have access to required diversification.

Mutual funds have already entered into a world of exciting innovative products. These products are now tailor made to suit specific needs of investors. Intensified competition and involvement of private players in the race of mutual funds have forced professional managers to bring innovation in mutual funds. Thus, mutual funds industry has moved from offering a handful of schemes like equity, debt or balanced funds to liquid, money market, sector specific funds, index funds and gilt edged funds. Beside this recently mutual funds have also introduced some special specific funds like children plans, education plans, insurance linked plans, and exchange traded funds. The result is that over the time Indian investors have started shifting towards mutual funds instead of traditional financial avenues.

Diversification in mutual funds is coming up with many new faces and as a result Indian mutual fund industry has been growing exceptionally well on the back of country's booming economy but still further mutual funds need to create 
more lucrative solutions to suit investor's expectations. The active involvement of mutual fund in economic development can be witnessed from dominant presence of mutual funds in worldwide capital and money market. Although mutual funds industry is responding very fastly to dynamism in investor's perception towards rewards still they are continuously following this race in their endeavor to differentiate their products responding to sudden changes in the economy. These acts of innovation include both invention and diffusion that persist to address information asymmetries.

Mutual funds as blessed with professional management use their diligent skills for efficient resource allocation by making markets more efficient, bringing transparency and foremost important risk management. Automated approaches designed by new technology and data mining is helping AMC's of mutual funds in strategic planning and investment decision making by uncovering the hidden patterns and predict future trends and behavior in financial markets. Intensive global competition and ICT enabled tools are promoting more demanding investors everyday. To satisfy the needs of investors' mutual funds are designing more lucrative and innovative tools considering the appetite for risk taking of individual investors. While designing these innovative fund scheme AMCs mainly consider for risk return trade off and after completely evaluating the various securities on various risk parameters new fund scheme is launched that can satisfy the quest of every investor to maximize the returns. Although risk and return are the two prime concerns for any mutual fund investment but investor's also go for sale charges, fund manager's reputation, fund history, management fees, clarity in disclosure, recommendation from media. So, whether it is a winner's game or loser's game the trick is to access the level of risk that investor wishes to assume and make certain that collection of assets fulfill their risk expectations. A successful investor is one who strives to achieve not less than rate of return consistent with risk assumed. Thus, it becomes imperative for the Mutual funds AMCs to judge the presence of rationality in investment behavior.

\section{Review of Literature}

Mutual funds have already attracted the attention of global practitioners and academicians but most of the existing research available is on either accelerating the return on funds or comparing it with benchmark fund schemes. Few studies are available that focus on investor's objective and considering risk orientation of investors that has been categorized as:

\subsection{Studies pertaining to Investor's Rationality: Risk-Return trade off}

Investors are generally more careful while making investment decision and presence of rationality in every investor demands higher return at minimum risk but when markets are efficient it is not possible to gain abnormal returns. Risk is generally, associated with various applications differently but in common it means negative connotation such as harm or loss or some undesirable action. Risk expressed by Kaplan and Garrick (1981) demonstrates that risk involves a factor of uncertainty and potential loss that might be incurred.

Elmiger and Kim (2003) elucidate risk as .the trade-off that every investor has to make between the higher rewards that potentially come with the opportunity and the higher risk that has to be borne as a consequence of the danger.

Although different literature available on risk define it variedly but in common the word risk refers to situations in which a decision is made whose consequences depend on the outcomes of future events having known probabilities(Lopes,1987). Risk from a strategic management perspective has been defined as one that is often taken as manager's subjective judgment of the personal or organizational consequences and it may result from a specific decision or action. Beta has been accepted as most appropriate measure of risk that describe the slope of any regression line i.e it reveals the volatility of a stock relative to a market benchmark (Sharpe 1966).

Uncertainty in investment decision prevails when Mutual fund AMCs skills and knowledge fail to have proper access of decision relevant information due to complexity of financial markets. This incapacity forces decision makers to adopt a simplified approach where risk is considered to be exogenous variable. Extensive literature available has proved that since Markowitz (1952) attempts have been made to resolve the conflicts of how decision makers should choose among composite alternatives that combine stochastic outcome as he was strongly in favor that choice for portfolio of securities is entirely different from securities that an individual investor holds (Bernstein 1996). Risk averse behavior of investors reflects the choice of investors to avoid risk or take negligible risk that means whenever an individual investor is given option to go for guaranteed return with probability one which are comparatively less than gambling return with probability less than one, chances are that he may go for guaranteed return.

\subsection{Studies relating to investment expectations}

Huge literature available on predicting stock market returns has proved that generally investors think high past stock market return predict high future return (De Bondt, 1993) even though there is no support for such belief in the data (Fama 1988). Further, evidence by Fisher and Statman (2000) have shown that individual investor's stock market return expectations are positively correlated with past returns. An attempt to relate stock expected returns and interrelated 
attributes can be well traced from Asset pricing Model that explains an assets expected return is positively related to its systematic market risk (Black 1972). The crux of these models is that risky portfolio yields higher return.

Although majority of investors who invest in mutual fund themselves are not clear with the objective and constraints of their investment but in addition to this most important critical gap that exist in this process is lack of awareness about presence of risk elements in mutual fund investment. The new marketing philosophy and strategies place special emphasis on recognition of customer needs in an effort to provide high level of quality services (Harrison, 2000). Study by Laukkanen (2006) explains that varied attributes present in a product or service facilitate customer's achievement of desired end-state and the indicative facts of study show that electronic services create value for customers in service consumption.

Return ambiguity and changes in risk perception of individual investor affect action taken in risky financial market. In a more complex situation taking rational decision is undoubtedly difficult but certainly not impossible. Computational complexities are not only the reason why rationality assumption is challenged rather challenges also come from cognitive reasoning (Anderson 1991) where question is how optima human beings are. A more realistic notion of rationality is bounded rationality defined by Simon (Simon 1957) that property of an agent who behaves in a manner that is nearly as optimal with respect to its goals as resource will allow. Here resource includes processing power, algorithm and time available to the agent.

\subsection{Studies relating to Financial Innovations in mutual funds}

New financial product and market designs, improved computer and telecommunication technologies and advances in theory of finance during past quarter century have led to dramatic changes in structure of mutual fund industry. Financial innovation is fighter promoted when the financial authorities recognize the obsolescence of existing statutory framework and deregulate the essential part of it (Suzuki 1986).

Financial system of any country comprises of regulatory bodies, financial institutions, financial products and financial markets and whenever the regulatory bodies try to interfee and restrict the actions of financial intermediaries, to sustain their position in the financial market, mutual funds (FMI) are required to come up with innovative and more lucrative solutions. Wide literature available on financial innovations has proved that regulatory restraints encourage innovations (Ben-Horim, 1977).

Study by Kane (1978) has described the process of avoiding regulations, as "loophole mining" which suggests that when regulatory constraints are so burdensome that large profits can be made by avoiding them, financial innovations is more likely to occur. These financial innovations may look for searching either entirely new product or making some structural changes in already built financial products to focus on investor's requirement. Financial innovation in case of mutual funds is an ongoing process but innovation and success are not parallel to each other. A large size of enterprise implies that product supported by adequate innovation is more likely to yield greater return (Schumpeter 1950). Study contrast to this by Scherer (1984) has suggested that smaller firms with only modest level of market power are more likely to be rapid innovators.

Mutual fund managers have to use various investment styles depending upon investor's requirement. Most of the empirical evidences have shown that mutual fund investor's purchase decision is influenced by past performance (Patel, et al. 1992). Research study by (Jones et al, 2007) has proved that a negative correlation exists between advertisement and fund quality. A common investor may expect that mutual fund should opt strategies that have been documented to produce superior returns in the past instead they follow to select portfolios that don't deviate markedly from market benchmarks (Lokonishok, Shleifer and Vishny, 1997).

\section{MF Service quality gaps: Loss Function}

Investor's satisfaction in case of mutual funds depends upon amount of trust and dependence that an investor places with AMC and in turn the benefits that are actually delivered to them. Although fund managers uses their expertise skills and diligence while investment but still dissatisfaction prevail among the investors and their experiences show that majority of mutual funds have shown underperformance in comparison to risk free return and reported that mutual funds were not able to compensate them for additional risk they have taken by investing in mutual funds (Anand, S. and Murugaiah, V.2004)

\subsection{Ambiguity of Investor's Expectations}

Concept of investor satisfaction is gaining importance for every MF organization because in addition to its contribution in a dominating way to the overall success of these organizations, it also shows them roadmap to retain and grow their business. SERVQUAL expectations have been variously defined as desires, wants, what a service provider should possess, normative expectations, ideal standards, desired services and the level of service a customer hopes to receive. Zeithaml, V (1993) expressed satisfaction of individual investor comprise of a range of varied parameters and is not easy to define but in general it means positive assessment. Where the growing demand of investor's expectation is 
following the way most of researcher admit the fact that working of customer's mind is a mystery which is difficult to solve (Dash, 2006). Customer satisfaction is subjective and even difficult to measure. To draft an accurate picture of customer satisfaction organizations should diligently use information - collecting tools and market research that will finally enable an organization to identify critical elements of customer satisfaction and further fine- tune their operations to achieve incremental improvements. Significant gaps that exist between service expectations and perceptions is right from the first step where AMCs are not found capable enough to translate investor's expectation, reason being financial intermediaries having inadequate knowledge and training are not able to communicate the message to each player effectively.

\subsection{Designing Gap}

Given the financial and resource constraints, AMCs are under increasing pressure to design services specifications in accordance to customer's requirement. Lack of upward communication from financial intermediaries to top management, inadequate commitment to service quality, absence of goal setting, inappropriate standardization are few reasons that are accountable for gaps that occur in designing of mutual fund services.

Minimizing risk and maximizing return are the two basic criteria that are given highest weightage while designing services specifications, as a rational investor. The purpose of designing quality services with improved quality from customer's perspective is to discover innovative ways that will provide value added services. Study by Ippolito (1992) documents the reaction of investors to performance in mutual fund industry. His findings have shown that poor relative performance results in investors shifting their assets into other funds. Therefore investing in quality of a product should be considered important not only to sustain reputation but to gain flow of profit that may come in the form of premium which investors will be willing to pay on trusted funds. Mutual fund organizations need to be extremely conscious at the time of designing and determining services standards. Service specifications designed by AMCs should match with customer's expected standards or with promised standards.

\subsubsection{Tolerance Zone: Risk}

Considering the level of income, constancy and stability of income etc investor's frame their own boundaries for risk bearing on any particular investment (Figure 1). Risk assumes wide definitions and distinguished from uncertainty as risk is measurable uncertainty about occurrence of an undesirable event. Williams (1964) proposed that sense of unpredictability of actual results of an action differing from possible predicted results in a given situation. Risk not only includes uncertainty and loss elements but time factor cannot be excluded from probability of risk. Doubt concerning the outcome in a given situation before the event occurs implies that there is something about the present situation that will be different in the future.

Tolerance Zone depicts the minimum and maximum specifications as described by investor for his willingness to assume risk represented by Upper Specification Limit and Lower Specification Limit. Investors based on his knowledge about the market volatility where he accepts the minimum risk, which he will have to bear on his investment, design these specification limits and maximum level is assumed depending upon his risk appetite and his willingness to maximize his ROI. However, Lack of management's commitment for services performance may deviate AMCs to come up with different performance standards. This deviation if less than the expected specification as proposed by investor will result in indifferent attitude of investors but in case the controllable limit as performed and delivered exceeds the upper specification limit of investors, it will certainly result in great dissatisfaction among the investors as AMCs will be held liable for the loss that will accrue to investors and that will lead investors think over incompetent professional management of mutual funds.

\subsubsection{Tolerance Zone: Return}

Investor's investment in any particular fund scheme of mutual funds depends upon anticipated return that will accrue from that particular investment. Mutual funds also offer innovative promising solutions for varied financial requirements of investors. Presently, Mutual fund organizations are also considered mature enough to understand and translate return requirement of individual investor's depending upon their demographic requirements. Again, mismatch between the boundaries as designed by investor's and actual performance standards may result in higher level of dissatisfaction among investors (Figure 2). Measurement criteria for loss to investors in case of return is almost opposite of discussed above. If actual delivered return from mutual funds exceeds the expected return it may provide positive reflections to investor's mind but will not satisfy them unless actually delivered return abnormally outperform expected return as in this case higher returns are credited to financial markets performances. Actual loss, if accrue to the investors through delivered return less than specified return it will bring great level of dissatisfaction among the investors because in this case investor's trust on skills and diligence of mutual funds AMCs get trodden. The only remedy to fill up these gaps is to create awareness among the investors that mutual funds performance is subject to market risk and instead of tempting them towards stocky returns, promises should be aligned with investor's specifications. 


\subsection{Delivery Gaps}

A rich diagnose for any mutual fund performance is evaluated through services they deliver in the form of extra ordinary return if they are able to deliver. Most of consumers admit the fact that increasing awareness have lead them to agree upon that despite of professional knowledge and skills fund performance is subjective of market volatility. So unlike other gaps that give a way to investor's satisfaction delivery gaps don't prevail in mutual fund services. Mutual fund's tendency to over promise however may push investor's expectation but to completely eliminate this particular gap mutual fund organization should show a true picture to investors and fund scheme to be provided should be framed after a complete analysis of risk appetite of investors. Among mutual funds delivering the promises are not only the criteria to evaluate fund services but courtesy, communication, empathy, responsiveness and reliability are some of the other parameters where mutual funds are found to be performing exceptionally well.

\section{Research Methodology}

In order to achieve the objective of developing an understanding about investor's risk and return perception towards mutual funds, a well structured questionnaire was designed. Responses of individual investors were collected through filled questionnaire with pre explained objectives of research. To reduce the complexity of data responses questionnaires were distributed among those investors only who had prior experience of mutual fund investment. For this purpose random sampling was ignored and selective systematic sampling was taken for consideration. For reliability of questionnaire 100 individual investors were selected from different regions of Punjab, which included selective investors who were assumed to be having complete knowledge of financial environment, and further they were existing investors of mutual funds. Age constraint considered in this questionnaire was minimum 18 years. Main focus of questionnaire was to obtain responses of individual investors regarding how they evaluate mutual funds services in terms of return and risk on their investment. Broad objectives of our research include:

E1: Evaluate Perception towards risk involved in mutual funds in comparison to other financial avenues

E2: Evaluate Perception towards return from mutual funds in comparison to other financial avenues.

E3: Identify critical gaps in mutual funds services towards transparency and disclosure practices.

E4: Uncovering the hidden problems investors encountered with because of unprofessional services of mutual funds.

E5: Understanding the willingness and ability to assume different levels of risk with varied parameters.

E6: Evaluating investor's perception towards risk volatility involved in mutual funds

\section{Analysis and Discussion}

Investor's purchase decision for mutual funds is influenced by chain of factors, out of this presence of risk and expected return being dominant one determines the direction where investor should opt for a particular investment avenue. Once an investor finalizes a particular investment avenue with calculated risk next factor accountable for his final decision is quality of service delivered. In this research a structured questionnaire was prepared to seek experiences of existing investors. These statements were analyzed and quantified on a 5 point likert scale used especially to measure the risk perception towards various financial avenues. Ranking and rating methodology was also followed to prioritize the investor's preferences. For convienence and better interpretation about different group of investor's responses, three categories were designed in order of age that include Aggressive investors, Active investors and reflexive investors. On the basis of income investors were again categorized into four classes that include basic investors i.e no-tax payer, Low tax payer i.e investor's in the lowest tax bracket, high tax payers which include upper middle class and lastly wealthy investors which include rich and financially stable investors.

\subsection{Relationship of Investor's Age and setting investment objectives}

For the sake of convenient understanding total investors are divided into three categories in relation to their age where investors below 30 years represent aggressive investors and active investors represent middle age investors and lastly investors above 50years are represented through reflexive investors. Data collected through questionnaire revealed that $41.4 \%$ aggressive investors invest with objective of capital appreciation and $24.1 \%$ prefer to invest for tax reduction. Active investors have got a hybrid of investment choices whereby $37.5 \%$ prefer to invest with the objective of tax saving and $31.2 \%$ invest it for capital appreciation. Opinion of reflexive investors is quite different from above two categories of investors, as $75 \%$ of them have given their preference for retirement benefits as main cause luring them towards investment avenues. A study at aggregate level tested by chi-square test has shown that investor's age is a considerable determinant in setting investment objectives which is significant at $1 \%$ level. $\left(\chi^{2}=54.26^{\mathrm{a}}, \mathrm{df}=12\right)$

\subsection{Relationship of investor's Income and setting investment Objective}

Income has also been considered as one of the important parameter that determines the objective of investment. Basic investors having low level of income are found to be more uncertain about future and $29.4 \%$ invest for future contingencies. Low taxpayers gave their opinion for tax saving as main investment objective (34.8\%) whereas $30.4 \%$ 
admit capital appreciation as investment objective. Choice of high tax payers is also found near to low tax payers where variance is only in terms of quantum as 50\% investors support capital appreciation as their broad objective and $33.3 \%$ opine for tax benefits. Opinion of wealthy investors is entirely different from rest of the investors as all of them have objective of capital appreciation as the broad investment objective. Chi-square is significant at $1 \%$ for income level. (Table 1)

\subsection{Investor's Risk Perception Analysis}

Presence of risk in any investment is a normal feature. Investor's behavior in terms of their willingness to accept risk depends upon their risk appetite or market sentiments that are spread in the market at the time of investment. Moreover, investor's knowledge and their optimism about market volatility also influence their decision to select risky investment. Table values depicting Average preference Scores (APS) reveals the fact that individual investors admit capital market instruments i.e Shares as the most risky investment in comparison to other investment avenues and mutual funds are opined to be next risky investment. APS also reveals that Investors don't deny the presence of risk in real estate but level of risk admitted is moderate and Government securities are admitted to be the least risky securities.

\subsubsection{Relationship of Investor's income to risk Perception for Insurance}

One of the objectives of study is to analyze risk perception of investors for mutual funds and identify critical gaps that prevail in mutual funds restructuring. In order to identify these gaps researcher is required to compare investors preference for various investment avenues and identify which investor group prefer what sort of investment and reason out the positives of those investment avenues which mutual fund organizations should involve while going for financial innovations in their existed fund schemes.

Insurance as an investment preference of investors emerges for uncertainty of future. Although Insurance is not considered as a most risky investment by majority of investors. Data collected through survey reveals that $47.1 \%$ basic investors consider it as least risky investment whereas $65.2 \%$ low taxpayers opine it as least risky investment. Fact is further supported by the responses gathered from high-income group investors where 50\% High taxpayers give last ranking to risk involved in insurance and 56\% wealthy investors also have last preference for risk involved in insurance. Going to aggregate level indicative facts exposed by survey prove that risk associated in insurance investment is significant for income as a parameter of investment decision-making. It is indicated by chi-square $\left(61.484^{\mathrm{a}}\right)$, which is significant at $1 \%$ level of significance. Chi square test shows that income status of investors and risk perception for insurance as an investment avenue is not independent $\left(\chi^{2}=23.043, \mathrm{df}=28\right)$

\subsubsection{Relationship of Investor's income to risk Perception for government securities}

Government securities are admitted as most secured securities and they have always been at the foremost preference of those investors who want to play safe game. When compared with other investment avenues nobody among the sample investor opined it as most risky investment. Data collected through survey revealed that $41.2 \%$ basic investors rank it at sixth position in terms of risk involved whereas 34.8\% low tax payer support this position of government securities in comparison to all other investment avenues. Further the fact is supported by opinion of high taxpayers where even $50 \%$ of them strongly agree to the fact that government securities are least risky investment and even they rank it at the sixth position but outlook of wealthy investors reveal that $66.7 \%$ of them have their opinion that government securities are least risky investment. Significance test as applied through chi square test although government securities are considered to be risk free investment but still income of investors and preference for government securities because of risk association are closely related as indicated by $\chi^{2}=61.540^{\mathrm{a}}$, df 24 . This value of chi square is significant at $1 \%$ level (asymp.sig .000).

\subsubsection{Relationship of Investor's income to risk Perception for Shares/Bonds}

Risk and Return for any investment are parallel to each other. Higher the risk, higher the return. Shares and bonds have been observed as the first preference of those investors who are willing to take risk. Capital market instruments being most risky investment are expected to yield above normal return that can be expected from any other investment avenue. Data collected from survey has proved this hypothesis that income of investors and risk perception for shares/bonds are related parameters of investment. $70.6 \%$ basic investors admit capital market instrument as most risky investment and rank it as first risky investment. $62.6 \%$ low taxpayers also opine that maximum risk is involved in shares and debentures when compared with other financial avenues whereas $100 \%$ high taxpayers and wealthy investors consider it as most risky investment. This statement is further tested by chi square test, which prove it to be significant at $1 \%$ level $\left(\mathrm{X}^{2}\right.$ $=32.251^{\mathrm{a}}$, df 16).

\subsubsection{Relationship of Investor's income and Risk Perception for Mutual Funds}

Responses collected from individual investors reveal the fact that reflection of risk on mutual funds is not as high as it was in case of shares and bonds. Although risk perception for mutual funds is also comparatively on higher side as $58.8 \%$ basic investors consider it as second risky investment and $65.2 \%$ low taxpayers consider it at the same position. 
Fact is further supported by the opinions of high taxpayers whereby $71.4 \%$ admit it as high risk involved and $66.7 \%$ also opine the same. The hypothesis was further tested at chi-square that shows that there is no close association of investor's income and their risk perception for mutual funds $\left(\mathrm{X}^{2}=11.061^{\mathrm{a}}, \mathrm{df}=18\right)$, which is not significant at $1 \%$ level. Thus, results of above data analysis make it clear that majority of individual investors don't consider mutual funds as highly risky investment but on a ranking scale it is considered to be on higher side when compared with other financial avenues. (Table 2(A) \& 2(B))

\subsection{Relationship of Income and investor's Perception for Returns}

Investor's income is one of the crucial determinants that set the objective of investment in various avenues. As shown in the table it can be clearly observed that individual investors mostly prefer shares as the best investment avenue in terms of return and quite close to it their next preference is for mutual funds. Insurance is considered as next preferred investment and government securities are considered to be last preferred investment.

\subsubsection{Investor' Perception for investment Return from insurance}

As discussed earlier investor's preference for insurance is not because they are tempted by the handsome return offered by insurance NBFCs but investors prefer to invest in mutual funds to reduce their fear of uncertainty. Moreover the fact is proved from the responses collected from individual investors when asked to rank investment avenues with return as a parameter for their evaluation. Data collected expose the fact that $35.3 \%$ of basic investors give their ranking as $5^{\text {th }}$ and $23.5 \%$ investors have ranked it at $7^{\text {th }}$ position. Among the low tax payers $30.4 \%$ also have their opinion that it is least preferred investment in terms of return as objective. Further ranking given by high tax payer investors also show that $66.7 \%$ have their opinion for it as least preferred investment and $33.3 \%$ wealthy investors rank it as moderately preferred investment avenue in terms of returns offered. Going to aggregate level the indicative facts disclose that a close association exist between income status of investors and their preference for insurance as an investment avenue which is proved by significance level of chi square at $1 \% \operatorname{level}\left(\chi^{2}=65.165^{\mathrm{a}}, \mathrm{df} 32\right)$

\subsubsection{Investor's Perception for Investment Returns from Government Securities}

Government securities being risk free securities are not preferred by the investors who want to gain above average return from their investments. Preference of government securities as an investment avenue is because of investor's choice to select securities that are completely free from any uncertainty and volatility. Results of responses collected from survey expose this fact that among the basic investors $29.4 \%$ rank it at $5^{\text {th }}$ position and further $29.4 \%$ admit it at $6^{\text {th }}$ position which explains that investors have moderate preference for government securities in terms of return as objective behind investment. Further data collected from survey for low taxpayer also support this fact whereby $39.1 \%$ again rank it at $5^{\text {th }}$ position and $50 \%$ high taxpayers rank it at $6^{\text {th }}$ position when compared with other investment avenues. Finally, wealthy investors have somewhat different perception for government securities whereby $66.7 \%$ investors have least preference for government securities. Fact of aggregate level when tested by chi-square has proved that a significant level of association exists between investor's income level and their perception for returns wise from government securities. These results are proved by $\chi^{2}=62.840^{\mathrm{a}}, \mathrm{df}=24$, which is significant at $1 \%$ level.

\subsubsection{Investor's Perception for Investment Returns from Shares/ Bonds}

As observed by survey responses of the individual investor's fact is clear that overall among other investment avenues capital market instruments are at the priority of investors but level of preference varies with different category/ level of income. Data responses of wealthy investors reveal the fact that majority of them i.e $66.7 \%$ admit it as first preference in terms of return as an investment objective. Among high tax payers $83.3 \%$ highly prefer this investment avenue in comparison to other investment avenues. Responses of low taxpayers do not reveal that these investors have absolute choice for capital market instrument as $39.1 \%$ have first preference for shares and debentures whereas $26.1 \%$ have second preference for capital market instruments. Basic investors also don't support wealthy investors to consider shared/bonds as first preference but $29.4 \%$ rank it at second or third position in terms of return as investment objective. Moving to aggregate level the fact is tested by chi-square which is significant at $1 \%$ level indicate that association exists between income status of investors and their preference for capital market instrument with return as objective $\left(\chi^{2}=\right.$ $\left.66.414^{\mathrm{a}}, \mathrm{df}=24\right)$

\subsubsection{Investor's Perception for Investment Returns from Mutual Funds}

Mutual fund as an investment avenue is preferred by those investors who don't want to take complete risk of capital market volatility or those investors who want to rely on professional knowledge of mutual funds AMCs. Survey results reveal the fact that very few investors rank mutual funds as most preferred investment avenue and rank it at first position. Among basic investors $29.4 \%$ rank it at $2^{\text {nd }}$ position and $23.5 \%$ put it at $3^{\text {rd }}$ position whereby $47.8 \%$ low tax payer admit it second preferred investment avenue in terms of return as an objective for investment. Majority of high tax payers $(66.7 \%)$ rank it at $3^{\text {rd }}$ position compared to other financial avenues. However, wealthy taxpayers also have their opinion of second position for mutual funds in terms of return provided by this investment. Results of aggregate level study are tested through chi square test that also proves that a significant relationship of interdependence exist 
between income level of investors and their perception for investment returns from mutual funds investment $\left(\chi^{2}=65.946^{\mathrm{a}}, \mathrm{df}=28\right)$, which is significant at $1 \%$ level. (Table $3(\mathrm{~A})$ and $\left.3(\mathrm{~B})\right)$

\subsection{Analysis of investor's Perception towards MFs Services}

Technological gadgets are extending their demand even in mutual funds market because of the proven solutions they are putting forward fund managers to tailor their fund schemes as per customer's desires. Information and Communication Technology enabled software programs are making it easier for fund managers to concentrate on individual needs of investors and come up with newly fangled financial innovations every time. Behind every financial innovation the two dominating forces where a trade off is required are minimizing the risk and maximizing the returns. Despite the major innovations recently introduced in MFs dissatisfaction among investors is clearly reflected which can be traced from their opinion towards mutual funds services. $61.11 \%$ basic investors admit that mutual funds completely disclose the risk involved in their investment whereas $30.4 \%$ low tax payers don't admit that mutual funds completely disclose presence of risk element. Opinion of high tax payers is also quite different and only $33.33 \%$ investors admit about mutual funds practice to disclose risk. Results obtained at aggregate level through ANOVA clearly reveal that average investors from all different categories don't differ in their opinion towards risk disclosure ( $\mathrm{F}$ value $=2.675, \mathrm{df}=99)$ which is significant at $5 \%$ level.

Results obtained from survey regarding investor's opinion towards disclosure of entry/exit load by MFs at the time of selling fund scheme shows that $41.1 \%$ basic investors admit it and $43.47 \%$ low tax payers also admit this. It has been observed that $28.57 \%$ high tax payers and $33 \%$ wealthy investors have positive response for mutual funds disclosure practices towards entry/exit load. It is evident from the above responses that majority of investors are not satisfied from mutual funds disclosure practice towards entry/exit load ( $\mathrm{F}$ value $=4.888, \mathrm{df}=99$ ) which is significant at $1 \%$ level. Investor's responses towards MFs services for disclosing the fund portfolio are also not found to be satisfactory as $35.29 \%$ basic investors and $34.78 \%$ low tax payers are found to be satisfied and agree that they were completely disclosed content of fund portfolio. Moreover responses of high tax payers $(33.33 \%)$ give their consent towards this practice. Evidences obtained are highly significant at $1 \%$ level $(\mathrm{F}$ value $=3.008, \mathrm{df}=99)$

Majority of investors get tempted by any fund scheme when illustrative examples are shown to them and puffed statements are given to give a lift to investor's optimism. Responses of investors towards whether they were disclosed that illustrative examples do not assure any guaranteed return yield the result that only $35.29 \%$ basic investors and $29.16 \%$ low tax payers admit it. Where responses of high tax payers $(33.33 \%)$ are quite similar to other responses wealthy investors are a bit different in their opinion as $67 \%$ of them admit that they were explained the concept. Results are verified by ANOVA that proves that average responses of investors towards mutual funds practice to disclose difference between hypothetical assumptions of market volatility and varied actual return are not different ( $\mathrm{F}$-value $=4.378, \mathrm{df}=99$ ) which is significant at $1 \%$ level.

Maturity and liquidity is one of the major concerns of every investor while investing. Investor's responses regarding disclosure of this practice by mutual funds yield the results that $64.7 \%$ basic investors and $69.56 \%$ low tax payer admit that they were clearly explained about maturity and liquidity of their investment. Responses from high tax payers are also quite close to above said categories whereby $66.67 \%$ admit this statement. Hypothesis testing by ANOVA has shown that on aggregate level majority of investors are satisfied from MFs disclosure practice. ( $\mathrm{F}$ value $=1.958, \mathrm{df}=99$ ) which is significant at $1 \%$ level. (Table 4 )

\subsection{Problems encountered in Mutual funds investment}

Investor's knowledge about capital market volatility and AMCs ability to control risk involved in mutual funds plays a dominating role in determining their satisfaction level. Based on this responses of investors were evaluated in terms of investors knowledge whereby investors with $73.3 \%$ low knowledgeable investors agree that actual return from mutual funds don't match with expected results whereas $66.7 \%$ investors with good working knowledge also admit the fact that investors are not found to be satisfied with returns delivered by mutual funds. Reason to prefer mutual fund investment lies in the fact that investors believe in the professional knowledge of mutual funds AMCs, responses of investors toward AMCs performance to behave in volatile market reveal the fact that $53.33 \%$ less knowledgeable investors agree with this statement that mutual funds AMCs are poor to respond to volatility in capital market and further investors with good working knowledge ( $80 \%$ ) also admit with the same opinion.

Cost charged by mutual funds in the form of fund management service charge that determines investor's opinion to prefer mutual funds. Responses of investors with less knowledge (73\%) admit high hidden cost charged by mutual funds whereby $87 \%$ investors with good working knowledge also admit and show their resentment towards fund services charged by mutual funds. Presence of awareness of individual investors for MFs working forces them to believe that their funds are invested according to investor's objectives described by them but survey evidence reveal the fact that $73.33 \%$ less knowledgeable investors and 53\% investors with good working knowledge admit their funds are 
not invested in the desired portfolio which should have been designed in accordance to their investment objectives. (Table 5)

\section{Investor Oriented Service Quality Arrangement (IOSQA)}

Prioritization of customer needs and expectation is critically important in order to satisfy investors. While MF's ability to reduce risk and magnify returns is expected to raise investor's satisfaction level but investors are also sensitive about overall service quality that is offered to them. Understanding service quality from the angle through which customer perceives it has still remained a mystery. However, Zeithaml (1987) endeavored to explain it as customer's judgment about overall superiority and Study by Parasuraman et.al, (1988) identified five determinants of service quality as discussed above. Johnston (1995) provided 18 different service dimensions that included access, aesthetics, attentiveness, availability, care, cleanliness, comfort, commitment, communication, competence, courtesy, flexibility, friendliness, functionality, integrity, reliability, responsiveness, security.

A secret catalyst for any breakthrough is to analyze potential impacts of a particular innovation and further to align those outcomes with the investor's objectives. IOSQA identifies seven C's that include Communication, Confidence, Credibility, Commitment, Concern, Competence, and Continuous improvement (CI) that should be fostered in order to ensure customer satisfaction. Investor oriented service quality arrangement (IOSQA) is a suggestive approach to align investor's expectations and AMC's actions towards complete satisfaction (Figure 3). This particular approach suggests AMCs should embrace 7Cs in order to transform their services in win-win game. Currently AMCs are required to flesh out existing fictions about investor's expectations and frame out completely new system that is conceptually richer and empirically more supportive in identifying what investors really need for which the root planning should start through effective communication. Moreover this communication process should not only be continued until investor finalizes his purchase decision but AMCs should also focus on post purchase reactions of investors. Mostly fund managers are wrongly blessed with misconceptions that success of their fund is directly related to heavy dose of innovation whereby they overlook post selection behavior of investors that comprise of the most relevant step that ensure final satisfaction.

Despite the fact realized, most of MFs are concentrating to improve only one parameter of investor's satisfaction and that is to improve the return they could provide to investors without paying any attention to quality of services expected by investors. Presence of intense competition in mutual fund industry is strongly pushing investors to change their attitude towards investors, so its high time to develop competence by showing their concern and innovating newly designed schemes that can assure them not only the financial benefits but also value added quality services. Mutual Funds AMCs have realized that the key mantra to success is designing new schemes with multi feature options for investors. Study by Garvin (1984) has shown that customers are generally benefited from the improvements that are offered by new features e.g enhanced quality product. Financial benefits offered in terms of return on Investment (ROI) is generally considered as a true parameter to evaluate fund performance but a true measure for it will be to what extent AMCs are able to satisfy investor's expectations by maintaining their credibility \& winning their confidence. In this context prioritization, preference building and close monitoring of mutual funds are essential for fund managers to make MFs most preferred financial avenue in coming years (Panda 2001).

Thus, the need of hour is not only to assess customer expectations and translate them but MF organizations are also required to ask how investors perceive Mutual Funds performance in comparison to investor's own expectations. Study by Brown and Eisenhardt (1998) suggest that developing technology, changing aspirations of stakeholders and increasing economic pressure all contribute to the need for organizations to significantly modify the way they are doing things. Existing literature available on Total Quality Management (TQM) suggests continuous improvement (CI) loop that should be evolved in order to deliver desired expectations. Among the varied systematic approaches of TQM, most applicable is Deming cycle or Plan-Do-Study-Act (PDSA) whereby each successive step is oriented towards improving firm's performance and also focus on customer satisfaction (Deming, 1995). Gelade and young (2005) examined the relationship between organization climate, employee attitude, customer satisfaction and sales performance and concluded teamwork climate, Job enablers and support climate are organizational climate variables, commitment is an employee attitude and customer satisfaction and sales achievement are organizational performance measures.

Despite higher ROI, many fund schemes fail and results in dissatisfaction among investors because the measures introduced are not followed continuously. So, the last ' $\mathrm{C}$ ' in this approach demands MFs true commitments that should be followed continuously. Relevance of communication with investors is not only to identify their expected and perceived needs but also to ensure understanding of dynamic needs, which need adjustments during post purchase stage. This continuous loop should be followed by AMCs admitting commitment towards investors, showing their concern for the trust investors have vested with them and extending their competence in order to regain investor's confidence. 


\section{Conclusion}

The present study endeavored to give a look on investor's perceptions towards risk-return trade off for mutual fund services. Understanding of investor's expectations from mutual funds has become necessary issue to study due to mutual funds inability to accelerate the required pace of growth. Moreover, volatility influencing stock market movements is turning most of investors to hold stocks with calculated risk, in the shape of mutual funds. Thus mutual funds can prove to be most preferred financial avenue provided it is put forth before investors in the desired form. Facts revealed in this study highlight the preferences of varied inverters who desire to invest in mutual funds but also require some innovations and added quality dimensions in existing services. The critical gaps identified in the study also provide the key information input regarding the discrepancies in existing framework of mutual funds which can be extremely beneficial to AMCs in designing more lucrative solutions to suit investor's expectations. Survey findings of this study have got significant managerial implications that can be used by AMCs in restructuring their existing practices and finally innovating new ways of service delivery.

\section{References}

Anand, S. \& Murugaiah, V. (2007). Analysis of components of investment performance - An Empirical study of Mutual funds in India. [Online] Available: http://www.ssrn.com

Anderson, J. (1991). Cognitive Architecture in a rational Analysis. Lawrence Erlbaum Associates, Hillsdale, pp. 1 - 24.

Ben, Horim. , Moshe \& William L. Silber. (1977). Financial Innovations: A Linear Programming Approach. Journal of Banking and Finance, November (1), pp. 447-465.

Bernstein, Peter L. (1996). Against the Gods: The Remarkable Story of Risk, New York. NY: John Wiley and Sons Inc.

Black, Fischer., Michael, Jensen. \& Myron, Sholes. (1972). The Capital Asset Pricing Model: Some Empirical tests, in Jensen (ed.). Studies in the theory of Capital Market. New York: Praege

Brown, S.L. \& Eisenhardt, K..M. (1998). Competing on the Edge, Boston. MA: Harvard Business School Press.

Cox, J. \& Dale, B.G. (2004). Service Quality and E-commerce: An exploratory analysis. Managing Service Quality, Vol. 11, no. 2, pp. 121-131.

Dash, Manoj Kumar and Mahapatra, D.M. (2006). Measuring customer satisfaction in banking industry. [Online] Available: http://www.indianmba.com

De Bondt, Werner (1993). Betting on trends: Intuitive forecast of financial risk and return. International Journal of forecasting, 9 (3), pp. 355-371.

Deming, W.E. (1995). The New Economics for Industry Government, and Education, 2nd Edition, Cambridge, MA: MIT Press.

Elmiger, G., \& Kim, S. (2003). Risk Grade your investments: Measure your risk \& create wealth. John Wiley \& Sons: Hoboken, NJ.

Fama, Eugene F., and Kenneth R. French. (1988). Permanent and Temporary components of stock prices. Journal of Political Economy, 96(2), pp. 246-273

Fisher, Kanneth, and Meier Statman. (2000). Investor sentiments and stock returns. Financial Analyst Journal, March/April, pp. 16-23.

Garvin D.A. (1984). what does product quality really mean?. Sloan Management Review, Fall 25-39.

Gelade, G.A., \& Young, S. (2005). Test of a Service Profit Chain Model in the Retail Banking Sector. Journal of Occupational and Organizational Psychology, 78, pp. 1-22.

Gronroos, C. (1990). Service Management and Marketing. Lexington Books, Lexington, MA.

Harrison, T. (2000). Financial Services marketing. Pearson Education Limited, Essex, England.

Ippolito, Richard. A. (1992). Consumer Reaction to Measures of poor Quality- Evidence from Mutual Fund industry. Journal of Law and Economics, 35, pp 45-70.

Johnston, B. (1995). The determinants of service quality: Satisfiers and dissatisfiers. International Journal of Service Industry Management, Vol.8, No. 5, pp. 53-71.

Jones, Michael. A. Lesseig, Vance. P \& Taylor, Valerie. A. (2007). Mutual Fund Advertising: Should investor take Notice. Journal of Financial Service Marketing, Vol. 12, pp. 242-254.

Kane, Edward. (1978). Interaction of financial and regulatory innovation. American Economic Review, May issue, No. 2.

Kaplan, S. \& Garrick, B. J. (1981). On the quantitative definition of risk. Risk Analysis, Vol.1, No.1, pp. 11- 27. 
Laukkanen, Tommi. (2006).Customer perceived value of e-financial services: a means-end approach. International journal of electronic finance, Vol.1, No.1, pp 5-17.

Lokonishok, Josef, Andrei Shleifer and Robert W .Vishny. (1997). What do money managers do. Working Paper, University of Illinois at Urbana Champaign.

Lopes, L. L. (1987). Between hope and fear: The psychology of risk. In L. Berkowitz (ed). Advances in experimental social psychology, San Diego, CA, US: Academic Press, Inc. pp 255-295.

Markowitz, Harry M. (1952). Portfolio Selection. Journal of Finance 7 (1), pp 77-91.

Panda,K.Tapan. and Prava, Nalini.(2001). Customer Orientation in designing Mutual Fund products. ICFAI journal of Applied Finance, Vol 7, No.V.

Panda, Tapan Kumar. (2001). Service quality value alignment through internal customer orientation in financial Services- An exploratory study in Indian banks. (accessed online.)

Parasuraman, A., Zeithaml, V.A. and Berry, L.L. (1988). SERVQUAL: a multiple item scale for measuring customer perceptions of service quality. Journal of Retailing, Vol. 64, pp. 12-40.

Patel, J., Zeckhauser, R., Hendricks, D. (1992). Investment Flows and Performance: Evidence from Mutual Funds, Cross Border Investments and New Issues. Harvard University, Cambridge, MA.

Rogers, E.M. (2003). Diffusion of Innovations, Free Press, New York.

Ranganathan, Kavitha.(2006). A study of fund selection behavior of individual investor towards MFs- with special reference to Mumbai. [Online] Available: http://www.ssrn.com

Scherer, F.M. (1984). Innovation and Growth: Schumpetarian Perspective. Cambridge, Mass.: MIT Press.

Schumpeter, Joseph A. (1950). Capitalism, Socialism and Democracy. $3^{\text {rd }}$ Edition, New York: Harper and Brothers.

Sharpe, W. F. (1966). Security prices, risk and maximal gains from diversification: Reply. Journal of Finance, pp 743-744.

Simon, H. (1957). Models of man: Social and Rational, Mathematical essay on rational behavior. New York: Wiley, pp $1-35$.

Suzuki. (1986). A comparative study of financial innovations, deregulation and reforms in Japan and US. Bank of Japan. Monetary Economic Series, 4(10).

Williams, C.A. and Heins, R. M. (1964). Risk management and insurance. New York, NY: McGraw-Hill Book Co.

Zeithaml, V., Berry, L., \& Parasuraman, A. (1993). The nature and determinant of customer expectation of service quality. Journal of the Academy of Marketing Science, 21(1), pp. 1-12.

Zeithaml, V.A. (1987). Defining and Relating Prices, Perceived Quality and Perceived Value. Marketing Science Institute, Cambridge, MA. 
Table 1. Chi-Square Test for Investment Objective

\begin{tabular}{|c|c|c|c|c|c|}
\hline Variable & $\begin{array}{c}\text { Likelihood } \\
\text { Ratio }\end{array}$ & $\begin{array}{c}\text { Linear } \\
\text { Association }\end{array}$ & Chi-Square & df & Significance \\
\hline Age & 15.421 & 1.064 & $54.260^{\mathrm{a}}$ & 12 & 0.000 \\
\hline Income & 24.707 & 0.399 & $63.295^{\mathrm{a}}$ & 20 & 0.000 \\
\hline
\end{tabular}

Table 2 (A). Risk Wise Average Preference Score and Standard Deviation Coefficient

\begin{tabular}{|c|c|c|c|c|c|}
\hline \multicolumn{2}{|c|}{ Investors } & Insurance & Govt. Securities & Shares & Mutual funds \\
\hline \multirow{2}{*}{ Basic Investors } & APS & 5.1176 & 5.8824 & 1.4118 & 2.6471 \\
\cline { 2 - 6 } & SD & 1.57648 & 1.40900 & 1.06412 & 1.27187 \\
\hline \multirow{2}{*}{ Low Tax Payers } & APS & 5.6522 & 6.0435 & 1.3913 & 1.5652 \\
\cline { 2 - 6 } & SD & 1.19121 & 1.10693 & 1.0000 & 2.4286 \\
\hline \multirow{2}{*}{ High Tax Payers } & APS & 5.1429 & 6.1429 & .00000 & .78680 \\
\cline { 2 - 6 } & SD & 1.06904 & 1.06904 & 1.0000 & 2.6667 \\
\hline \multirow{2}{*}{ Wealthy Investors } & APS & 4.3333 & 6.6667 & .00000 & 1.15470 \\
\cline { 2 - 6 } & SD & 2.30940 & .57735 & 1.3200 & 2.5800 \\
\hline Total & APS & 5.3200 & 6.0400 & 1.05830 & 1.21370 \\
\cline { 2 - 6 } & SD & 1.39152 & 1.17734 & & 1.3250 \\
\hline
\end{tabular}

Table 2(B). Chi-Square Test for Risk Perception

\begin{tabular}{|c|c|c|c|c|c|}
\hline Variable & $\begin{array}{c}\text { Likelihood } \\
\text { Ratio }\end{array}$ & $\begin{array}{c}\text { Linear } \\
\text { Association }\end{array}$ & Chi-Square & df & Significance \\
\hline Insurance & 28.654 & 0.45 & $75.106^{\mathrm{a}}$ & 28 & 0.000 \\
\hline $\begin{array}{c}\text { Government } \\
\text { Securities }\end{array}$ & 22.406 & 3.39 & $61.54^{\mathrm{a}}$ & 24 & 0.000 \\
\hline Shares/Bonds & 17.554 & 0.192 & $32.251^{\mathrm{a}}$ & 16 & 0.001 \\
\hline Mutual Funds & 12.158 & .054 & $11.061^{\mathrm{a}}$ & 18 & 0.892 \\
\hline
\end{tabular}


Table 3 (A). Return wise Average preference Score and Standard Deviation Coefficient

\begin{tabular}{|c|c|c|c|c|c|}
\hline \multicolumn{2}{|c|}{ Investors } & Insurance & Govt. Securities & Shares & Mutual funds \\
\hline \multirow{2}{*}{ Basic investors } & APS & 4.8235 & 5.3529 & 2.8824 & 3.1176 \\
\cline { 2 - 6 } & SD & 1.87867 & 1.36662 & 1.65387 & 1.83311 \\
\hline \multirow{2}{*}{ Low tax payer } & APS & 5.7391 & 5.2609 & 2.0000 & 2.7826 \\
\cline { 2 - 6 } & SD & 1.38883 & 1.21421 & .95346 & 1.04257 \\
\hline \multirow{2}{*}{ High Tax Payers } & APS & 5.0000 & 6.0000 & 2.4286 & 2.2857 \\
\cline { 2 - 6 } & SD & 2.00000 & .81650 & .78680 & .95119 \\
\hline \multirow{2}{*}{ Wealthy Investors } & APS & 5.0000 & 6.3333 & 1.3333 & 2.0000 \\
\cline { 2 - 6 } & SD & 1.00000 & 1.15470 & .57735 & 1.00000 \\
\hline \multirow{2}{*}{ Total } & APS & 5.2800 & 5.4600 & 2.3200 & 2.7800 \\
\cline { 2 - 6 } & SD & 1.65418 & 1.23239 & 1.26878 & 1.35962 \\
\hline
\end{tabular}

Table 3 (B). Chi-Square test for Investment Returns

\begin{tabular}{|c|c|c|c|c|c|}
\hline Variable & $\begin{array}{c}\text { Likelihood } \\
\text { Ratio }\end{array}$ & $\begin{array}{c}\text { Linear } \\
\text { Association }\end{array}$ & Chi-Square & df & Significance \\
\hline Insurance & 27.71 & 2.66 & $65.165 \mathrm{a}$ & 32 & 0.000 \\
\hline Govt Securities & 22.672 & 4.729 & $62.84 \mathrm{a}$ & 24 & 0.000 \\
\hline Shares/Bonds & 27.758 & 2.411 & $66.414 \mathrm{a}$ & 24 & 0.001 \\
\hline Mutual Funds & 28.246 & 0.605 & $65.946 \mathrm{a}$ & 28 & 0.000 \\
\hline
\end{tabular}

Table 4. Investor's Perception towards Mutual Fund Services

\begin{tabular}{|c|c|c|c|c|}
\hline Variable & Mean & Variance & F value & Sig \\
\hline Risk Disclosure & 2.64 & 0.969 & 2.675 & 0.019 \\
\hline Entry/Exit Load & 2.4 & 0.7744 & 4.888 & 0.000 \\
\hline Portfolio contents & 2.8 & 0.855 & 3.008 & 0.010 \\
\hline Illustrative examples & 2.9 & 1.02 & 4.378 & 0.001 \\
\hline Maturity/Liquidity & 2.36 & 0.765 & 1.958 & 0.06 \\
\hline \% Fund Allocation & 3.06 & 1.56 & 2.868 & .013 \\
\hline
\end{tabular}

Table 5. Problems in Mutual Fund Investment

\begin{tabular}{|c|c|c|c|c|}
\hline Variable & Mean & Variance & F value & Sig \\
\hline Actual returns v/s Expected returns & 2.06 & 0.954 & 2.536 & .026 \\
\hline $\begin{array}{c}\text { Ability to respond towards market } \\
\text { volatility }\end{array}$ & 2.32 & 0.834 & 5.549 & .000 \\
\hline High hidden cost & 1.9 & 0.908 & 4.138 & .001 \\
\hline Investment v/s investor's objective & 2.78 & 1.23 & 4.439 & .001 \\
\hline
\end{tabular}




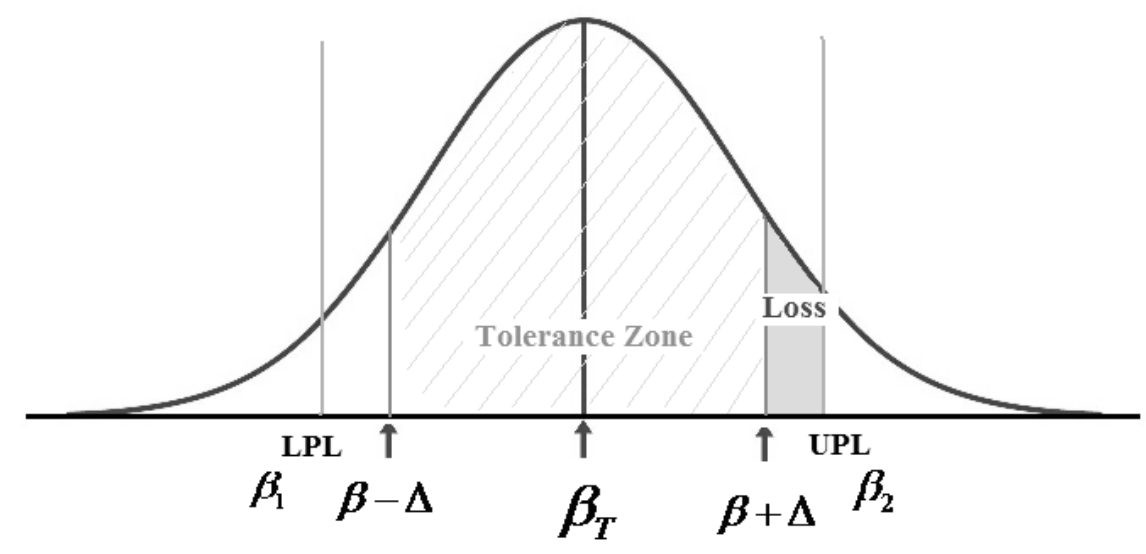

Figure 1. Tolerance Zone: Risk

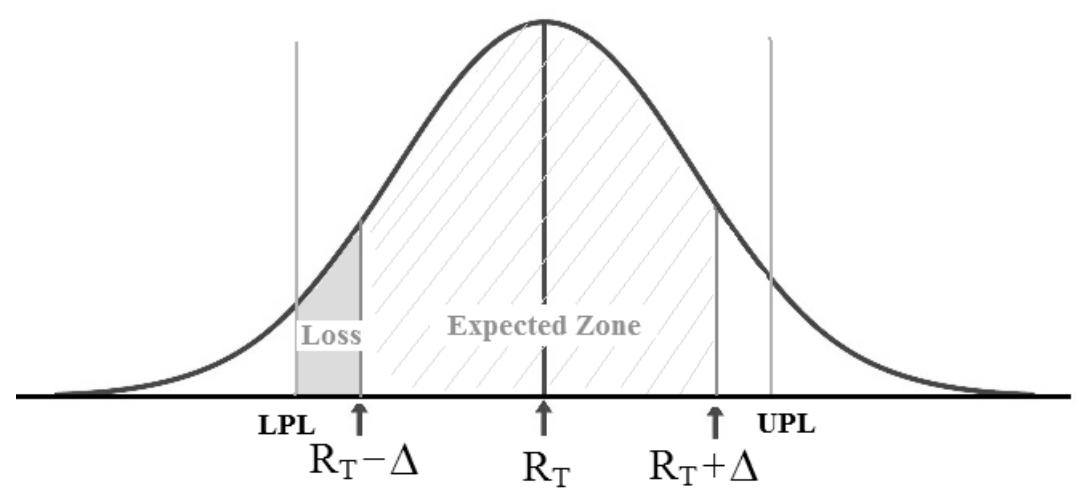

Figure 2. Tolerance Zone: Return 


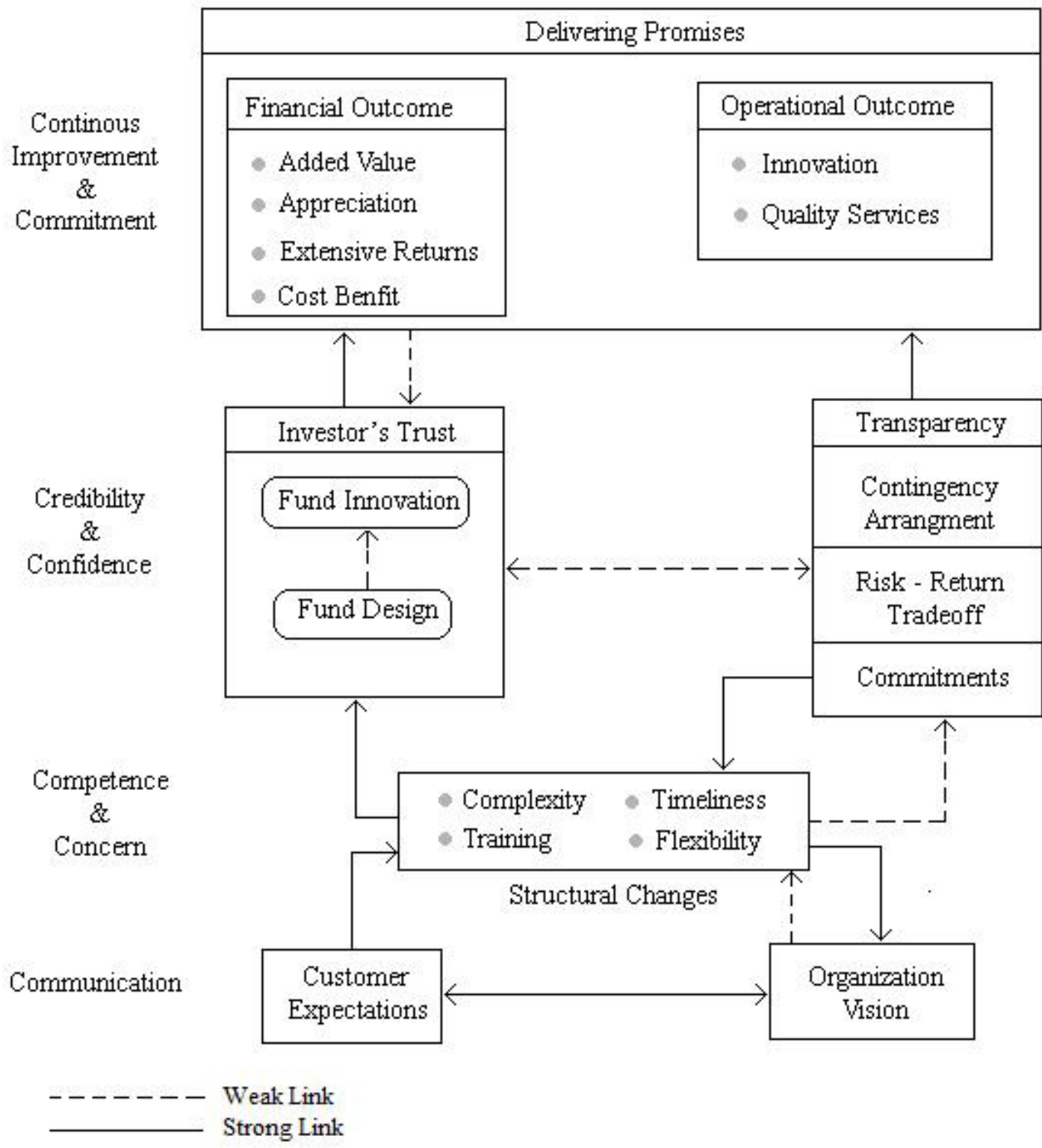

Figure 3. IOSQA 